Vol-5, Issue-1, 2021 (IJEBAR)

E-ISSN: 2614-1280 P-ISSN 2622-4771

https://jurnal.stie-aas.ac.id/index.php/IJEBAR

\title{
EFFECT OF CORPORATE GOVERNANCE ON INTELLECTUAL CAPITAL DISCLOSURE
}

\author{
Hesniati $^{1^{*}}$ \\ Universitas Internasional Batam \\ E-mail: hesniati.lec@uib.ac.id
}

\begin{abstract}
Disclosure of intellectual capital is essential in providing information about the company's intellectual assets in knowledge economy era. The purpose of this study is to acquire empirical evidence of how corporate governance influences the disclosure of intellectual capital of Indonesian listed companies in Kompas 100 Index. The sample consisted of 48 listed companies that had been sorted and tested using multiple linear regression methods. The outcome of the study showed that independent commissioner composition had no effect on intellectual capital disclosure. Board size, audit meeting, and audit committee have a significant positive effect on intellectual capital disclosure.
\end{abstract}

Keywords: $\quad$ Corporate governance, Intellectual capital, Disclosure

\section{Introduction}

The switchover of economy from technological-based to knowledge-based requires an urgent change in disclosure of intangible assets. Intellectual capital (IC) emphasizes all intangible corporate that can be utilized to achieve competitive advantage (Hesniati, Margaretha, \& Kristaung, 2019). The economy value of a company stands in the generation of intellectual capital based on a knowledge-based economy (Naimah \& Mukti, 2019).

The ability of firm to disclose IC will able to increase firm value, achieve competitive advantage, intensify internal control, improve capability of asset management, enhance the characteristics of information disclosed, and narrow risk-related business decisions ((Al-Sartawi, 2018). The organization discloses information about IC to provide a comprehensive view of the activities carried out by the organization and its impact on overall organizational performance (Sharma \& Dharni, 2017). IC is important in building company value and encouraging company to disclose IC in order to survive the competitive business environment.

IC is the dominant resource in knowledge-based economy, nevertheless traditional accounting practices only partially acknowledge the value of a firm's IC. Disclosure of IC must be seen as a tool to improve decision making (Cabrita, Ribeiro da Silva, Gomes Rodrigues, \& Muñoz Dueñas, 2017). A new issue of IC focused on understanding the management of IC disclosure (IDC). IC integration into corporate reports is a major problem that arises and has not yet been resolved in IC management (Castro, Díez-Vial, \& Delgado-Verde, 2019).

The implementation of effective corporate governance mechanism can help companies preserve its values by involving decision makers to develop intellectual capital. Maintaining ICD depends on corporate governance practices. Corporate governance enhances reporting quality of IC which indicated the ability of company in managing assets and firm value (Al-Sartawi, 2018). Corporate governance and voluntary disclosure of IC improve investor protection and enhance the efficiency of capital market (Gan, Saleh, Abessi, \& Huang, 2013).

The urgency of disclosure in intellectual capital is incongruent with existing practices in Indonesia. Level of ICD by listed companies in Indonesia only $47 \%$ according to the research 
International Journal of Economics, Business, and Accounting Research (IJEBAR)

Peer Reviewed - International Journal

Vol-5, Issue-1, 2021 (IJEBAR)

E-ISSN: 2614-1280 P-ISSN 2622-4771

https://jurnal.stie-aas.ac.id/index.php/IJEBAR

conducted by (Isnalita \& Romadhon, 2018). In this context, this study aims to explore the role of corporate governance mechanism on ICD in Indonesian listed companies. Regulators and business management will be able to improve corporate governance mechanism and quality of reporting IC.

\section{Literature review and hypotheses}

\section{Agency Theory}

Theoretically, most of managers (agents) in company management have responsible and duty to maximize the wealth of shareholders (principals). However, agency problems arise when managers deviate from the goal of shareholders by placing their personal goals ahead. When problems arise, it will incur agency cost and a loss for companies. Therefore, companies establish corporate governance practices to ensure that managers will act in ways that are in a line with the interests of shareholders (Gitman \& Zutter, 2015).

\section{ICD}

IC stands for all the knowledge possessed by companies and creates value for the organization. Disclosure of IC in the financial statements is one way to prove that the statement describes the company's activities that are credible and integrated. Sveiby (1997) developed a framework of ICD with 3 subcomponents. (1) Internal capital produced by staff and owned by company; (2) external capital created by company's associations; (3) human capital is the value created by employee's skills through education and training (Al-Hajaya, Altarawneh, \& Altarawneh, 2019).

\section{Corporate Governance}

Several studies have shown that corporate governance has influence in the development of ICD. Effective corporate governance mechanisms can promote IC disclosure. Independent commissioner composition (ICC) has positive relationship on ICD as the higher percentage composition the more often to disclose information (Puwanenthiren, 2018). Independent commissioners represent shareholders to monitor company's activities and they are capable in influencing the disclosure policy (Mehrotra, Malhotra, \& Pant, 2018). Independent commissioners may increase effectiveness to prevent any fraudulent related on financial statement (Arifin, 2016).

Board size (BS) has positive effect on ICD in capital market which explained a larger board provide greater management oversight and access to a wider resources (Alfraih, 2018). The larger size of board is bringing greater set of expertise and experience members to increase efficiency and effectiveness in disclose IC information. Knowledge exchange in strategic value of IC leads directors to participate in disclosing IC decision (Tejedo-Romero, Araujo, \& Emmendoerfer, 2017).

A high frequency of audit committee meetings (AM) in a company proves more often to disclose its intellectual capital (Naimah \& Mukti, 2019). AM activity is an important factor in enhancing ICD to reduce information asymmetry. Frequently meeting will increase higher level oversight of company reporting issues including ICD (Li, Mangena, \& Pike, 2012). Frequency of meeting also improve role of audit committees effectively in company reporting quality (Haji, 2015).

AC has positive effect on ICD because audit committee's responsibilities are closely related to the company's sustainability in the future and ensure that the interests of shareholders 
International Journal of Economics, Business, and Accounting Research (IJEBAR)

Peer Reviewed - International Journal

Vol-5, Issue-1, 2021 (IJEBAR)

E-ISSN: 2614-1280 P-ISSN 2622-4771

https://jurnal.stie-aas.ac.id/index.php/IJEBAR

are well protected (Nurlis, 2018). Gan et al. (2013) found size of audit committee (AC) has positive effect on ICD and stated audit committee create pressure on companies to provide more voluntary information. Audit committee have an assurance role in information disclosure practices in a company (Haji, 2015). Hereafter, the hypotheses are generated as below:

$\mathrm{H}_{1}$ : independent commissioner composition (ICC) has positive effect on ICD

$\mathrm{H}_{2}$ : board size (BS) has positive effect on ICD

$\mathrm{H}_{3}$ : audit meeting (AM) has positive effect on ICD

$\mathrm{H}_{4}$ : audit committee (AC) has positive effect on ICD

Figure 1. Theoretical Framework

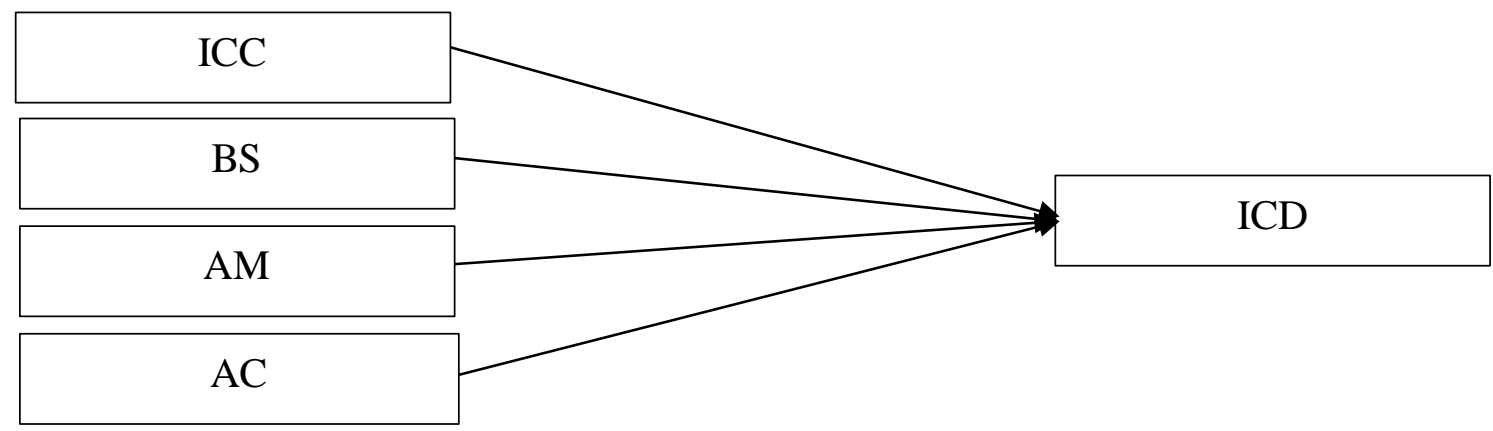

Source: Writer (2019)

\section{Research Method}

This study is using financial statement from 48 companies listed in Kompas100 index consecutively 5 years from 2012 to 2016 . Kompas100 is an index that measures top 100 of companies with large market capitalization, high liquidity, and good fundamentals in Indonesia Stock Exchange. Companies listed in the index were considered to have good management by the market. Thus, they were expected to uphold the principle of accountability through ICD. All hypotheses tested using multiple regression linear method by SPSS.

The dependent variable is the ICD that measured by ICD index (ICDI) based on the 24 item of IC framework, it consists 8 items of internal capital, 8 items of external capital, and 8 items of human capital. This ICDI is developed by Sveiby (1997) and modified by Petty and Guthrie (2000). Many of prior studies on ICDI have used this IC framework such as Susanto, Pradipta, and Handojo (2019), Alfraih (2018), and Alfraih (2017). In this approach, the value "0" is set as item did not reported and the value " 1 " is set if the item was reported. The ICDI for each company is calculated by dividing the total score obtained by the company by the maximum total score that may be appropriate for the company. 
International Journal of Economics, Business, and Accounting Research (IJEBAR)

Peer Reviewed - International Journal

Vol-5, Issue-1, 2021 (IJEBAR)

E-ISSN: 2614-1280 P-ISSN 2622-4771

https://jurnal.stie-aas.ac.id/index.php/IJEBAR

Table 1. IC Framework

\begin{tabular}{|l|l|l|}
\hline Internal Capital & External Capital & Human Capital \\
\hline Intellectual property & Brands & Education \\
\hline Corporate culture & Customers & Know-how \\
\hline Patents/Copyrights/Trademark & Company names & Work-related knowledge \\
\hline Information system & Customer satisfaction & Academic qualification \\
\hline Networking system & Customer loyalty & Professional qualification \\
\hline Management process & Distribution channel & Human capital/resources \\
\hline Management philosophy & Business collaboration & Training \\
\hline Financial relations & Licensing agreement & Entrepreneurial spirit \\
\hline
\end{tabular}

Source: Alfraih (2018)

The independent variables used in this study are ICC, BS, AM, and AC. Independent commissioner composition is calculated by number of independence commissioner divided total numbers of board commissioner (Isnalita \& Romadhon, 2018). Board size is calculated by total numbers of members from board of directors (Alfraih, 2018). Audit meeting is number of committee audit meeting (Nurlis, 2018). Audit Committee is counted by total numbers of audit committee member in company (Isnalita \& Romadhon, 2018).

\section{Results and Discussion}

\subsection{Results}

The database was analysed and detected 12 outliers and it has been eliminated before testing hypotheses. Examination of normality, multicollinearity, and heteroscedasticity were performed and have not violated multiple regression assumptions. Statistical data results and hypotheses testing are shown below:

Table 1. Descriptive Statistics

\begin{tabular}{lccccc}
\hline & N & Minimum & Maximum & Mean & Std. Deviation \\
\hline ICC & 228 & 0.1429 & 0.7143 & 0.4122 & 0.1071 \\
BS & 228 & 3.0000 & 13.0000 & 6.8333 & 2.1401 \\
AM & 228 & 2.0000 & 49.0000 & 12.5175 & 11.6500 \\
AC & 228 & 2.0000 & 7.0000 & 3.6798 & 1.0402 \\
ICDI & 228 & 0.3333 & 0.9167 & 0.6329 & 0.1109 \\
Valid N & 228 & & & & \\
(listwise) & & & & & \\
\hline
\end{tabular}

Descriptive statistics indicate the average company has an ICDI of $63.29 \%$, which indicates an increase in intellectual capital disclosure in companies in Indonesia compared with research from (Isnalita \& Romadhon, 2018). The average of ICC is $41.22 \%$, BS is 6.8333 directors, AM 12.51 times in a year, AC is 3.6798 auditors in a company. 
International Journal of Economics, Business, and Accounting Research (IJEBAR)

Peer Reviewed - International Journal

Vol-5, Issue-1, 2021 (IJEBAR)

E-ISSN: 2614-1280 P-ISSN 2622-4771

https://jurnal.stie-aas.ac.id/index.php/IJEBAR

Table 2. Hypotheses Results

\begin{tabular}{llll}
\hline Variable & B & Sig. & Result \\
\hline (Constant) & 0.463 & 0.000 & \\
ICC & -0.058 & 0.364 & $\mathrm{H}_{1}$ rejected \\
BS & 0.010 & 0.004 & $\mathrm{H}_{2}$ approved \\
AM & 0.003 & 0.000 & $\mathrm{H}_{3}$ approved \\
AC & 0.027 & 0.000 & $\mathrm{H}_{4}$ approved \\
\hline
\end{tabular}

Dependent variable: ICDI

\subsection{Discussion}

The results show $\mathrm{H}_{1}$ is rejected, ICC has no significant influence on ICD. The greater proportion of independent directors does not guarantee the representation of the interests of shareholders. The function of independent commissioners as monitoring is only to fulfil corporate governance rules, not to enforce corporate governance (Nurlis, 2018). This condition also reveals the greater size of ICC will decrease the disclosure of IC. This finding is inconsistent with Uzliawati and Djati (2015) and Mehrotra et al. (2018).

Based on the results, $\mathrm{H}_{2}$ is approved and reveals BS has positive significant effect on ICD. The larger board is more likely to increase knowledge sharing between directors and enhance their effectiveness to disclose more information of IC. This study is consistent with Alfraih (2018) and Tejedo-Romero et al. (2017). Large board increase more transparency (Kamat, 2019) and proved by descriptive data in this study with average of 6 board director in Indonesian company.

AM has significant positive effect on ICD, thus $\mathrm{H}_{3}$ is approved. This result is consistent with Naimah and Mukti (2019), Haji (2015), and Li et al. (2012) who examined the same field. The higher frequency of AM will increase financial reporting in disclosing IC information. Descriptive statistics show average 12 meeting a year that means audit committees have opportunities every month to share knowledge and effectively enhancing company reporting quality.

$\mathrm{H}_{4}$ reveals AC has significant positive effect on ICD. This finding supports the argument that effectiveness of $\mathrm{AC}$ will enhanced if its resources is well. AC has ability to oversee the information provided in financial reporting ( $\mathrm{Li}$ et al., 2012). The participation of audit committee members in each meeting routinely allows them to discuss all issues related to the company's activities including integrated reporting (Chariri \& Januarti, 2017). Also, larger size of audit committee indicates the larger groups to able share different knowledge and enhance the potential to release information of a hidden values in a company (Haji, 2015).

Value of adjusted $\mathrm{R}^{2}$ is 0.241 which means all independent variables can only explain 24.10 per cent of variation in the amount of ICD. Overall, this regression model is significant by F-test $(\mathrm{F}=0.000)$.

\section{Conclusion}

This study was motivated due to disclosure in intellectual capital is incongruent with existing practices in Indonesia. Level of ICD by listed companies in Indonesia only $47 \%$ according to the research conducted by Isnalita and Romadhon (2018). Therefore, purpose of this study is to explore and acquire empirical evidence of how corporate governance in influencing the 
International Journal of Economics, Business, and Accounting Research (IJEBAR)

Peer Reviewed - International Journal

Vol-5, Issue-1, 2021 (IJEBAR)

E-ISSN: 2614-1280 P-ISSN 2622-4771

https://jurnal.stie-aas.ac.id/index.php/IJEBAR

disclosure of intellectual capital of Indonesian listed companies in Kompas 100 Index from 2012 to 2016.

The results reveal audit characteristics like size of audit committees and audit committee meetings have significant positive effect on ICD. That means the larger group of audit and frequency meeting will improve company reporting quality and release more information of hidden value in a company such as IC. The board size also has positive significant impact on ICD which indicates larger board more likely to disclose information of IC. However, ICC has no influence and negative relationship on ICD.

This study contributes theoretical and practical perspective. Theoretically, it provides an understanding of the relationship between IC disclosure and corporate governance mechanisms. The finding provides empirical support for effectiveness of corporate governance mechanisms in improving ICD. Practically, the result can be used as guideline for regulators and company management to promote transparency information in company reporting.

There are several limitations when conducting this study. First, this study on used large capitalization companies and 5 years database. Second, the independents variable used in the study is limited. Therefore, suggestion for future research is extend research period or examine by sectors. Future research is advised to add number of research variables to represent corporate governance mechanism and ICD

\section{References}

Al-Hajaya, K., Altarawneh, M. S., \& Altarawneh, B. (2019). Intellectual Capital Disclosure by Listed Companies in Jordan : A Comparative Inter-sector Analysis. International Review of Management and Marketing, 9(1), 109-116. https://doi.org/10.32479/irmm.7381

Al-Sartawi, A. M. A. M. (2018). Corporate governance and intellectual capital: Evidence from Gulf Cooperation council countries. Academy of Accounting and Financial Studies Journal, 22(1), 1-12.

Alfraih, M. M. (2017). The value relevance of intellectual capital disclosure: empirical evidence from Kuwait. Journal of Financial Regulation and Compliance, 25(1), 22-38. https://doi.org/10.1108/JFRC-06-2016-0053

Alfraih, M. M. (2018). The role of corporate governance in intellectual capital disclosure. International Journal of Ethics and Systems, 34(1), 101-121. https://doi.org/10.1108/IJOES-02-2017-0026

Arifin, J. (2016). Corporate Governance and Intellectual Capital on Financial Performance of Bank Sector Companies: Indonesia Stock Exchange 2008-2012. Journal of Administrative Sciences and Policy Studies, 4(1), 61-82. https://doi.org/10.15640/jasps.v4n1a4

Cabrita, M. R. M. F., Ribeiro da Silva, M. L., Gomes Rodrigues, A. M., \& Muñoz Dueñas, M. P. (2017). Competitiveness and disclosure of intellectual capital: an empirical research in Portuguese banks. Journal of Intellectual Capital, 18(3), 486-505. https://doi.org/10.1108/JIC-11-2016-0112

Castro, G. M., Díez-Vial, I., \& Delgado-Verde, M. (2019). Intellectual capital and the firm: evolution and research trends. Journal of Intellectual Capital, 20(4), 555-580. https://doi.org/10.1108/JIC-12-2018-0221

Chariri, A., \& Januarti, I. (2017). Audit committee characteristics and integrated reporting: Empirical study of companies listed on the Johannesburg stock exchange. European Research Studies Journal, 20(4), 305-318. https://doi.org/10.35808/ersj/892 
International Journal of Economics, Business, and Accounting Research (IJEBAR)

Peer Reviewed - International Journal

Vol-5, Issue-1, 2021 (IJEBAR)

E-ISSN: 2614-1280 P-ISSN 2622-4771

https://jurnal.stie-aas.ac.id/index.php/IJEBAR

Gan, K., Saleh, Z., Abessi, M., \& Huang, C. C. (2013). Intellectual capital disclosure in the context of corporate governance. International Journal of Learning and Intellectual Capital, 10(1), 52-70. https://doi.org/10.1504/IJLIC.2013.052077

Gitman, L. J., \& Zutter, C. J. (2015). Principle of managerial finance (14th ed.). Pearson Education Limited.

Haji, A. A. (2015). The role of audit committee attributes in intellectual capital disclosures: Evidence from Malaysia. Managerial Auditing Journal, 30(8-9), 756-784. https://doi.org/10.1108/MAJ-07-2015-1221

Hesniati, H., Margaretha, F., \& Kristaung, R. (2019). Intellectual capital, knowledge management practices and firm performance. European Journal of Business and Management Research, 4(6). https://doi.org/10.24018/ejbmr.2019.4.6.133

Isnalita, I., \& Romadhon, F. (2018). The Effect of Company Characteristics and Corporate Governance on the Practices of Intellectual Capital Disclosure. International Research Journal of Business Studies, 11(3), 217-230. https://doi.org/10.21632/irjbs.11.3.217-230

Kamat, G. B. (2019). Role of Corporate Governance in the Voluntary Disclosure of Intellectual Capital. International Research Journal of Business Studies, 12(3), 243-256. https://doi.org/10.21632/irjbs.12.3.243-256

Li, J., Mangena, M., \& Pike, R. (2012). The effect of audit committee characteristics on intellectual capital disclosure. British Accounting Review, 44(2), 98-110. https://doi.org/10.1016/j.bar.2012.03.003

Mehrotra, V., Malhotra, A. K., \& Pant, R. (2018). Intellectual Capital Disclosure by the Indian Corporate Sector. Global Business Review, 19(2), 376-392. https://doi.org/10.1177/0972150917713562

Naimah, Z., \& Mukti, N. A. (2019). The influence of audit committee's and company's characteristic on intellectual capital disclosure. Asian Journal of Accounting Research, 4(2), 170-180. https://doi.org/10.1108/ajar-05-2019-0036

Nurlis. (2018). The Effect of Good Corporate Governance on Intellectual Capital Disclosure and Its Impact on Company Performance: A Study on Banking Companies Listed on BEI. European Journal of Business and Management, 10(10), 126-133.

Petty, R., \& Guthrie, J. (2000). PageRank: When order changes. Journal of Intellectual Capital, 1(2), 155-176. https://doi.org/10.1007/978-3-540-71496-5_54

Puwanenthiren, P. (2018). Is corporate governance and intellectual capital disclosure related a Sri Lankan case. Journal of Business Studies, 5(2), 45. https://doi.org/10.4038/jbs.v5i2.36

Sharma, S., \& Dharni, K. (2017). Intellectual capital disclosures in an emerging economy: status and trends. Journal of Intellectual Capital, 18(4), 868-883. https://doi.org/10.1108/JIC-09-2016-0092

Susanto, Y. K., Pradipta, A., \& Handojo, I. (2019). Determinant of Intellectual Capital Disclosure. International Journal of Business, Economics and Law, $20(5 \mathrm{dec}), 83-89$.

Sveiby, K.-E. (1997). The New Organizational Wealth - Managing and Measuring Knowledge-based Assets. SanFrancisco. CA.: Berrett-Koehler Publishers.

Tejedo-Romero, F., Araujo, J. F. F. E., \& Emmendoerfer, M. L. (2017). Corporate governance mechanisms and intellectual capital. Review of Business Management, 19(65), 394-414. https://doi.org/10.7819/rbgn.v19i65.3024 
International Journal of Economics, Business, and Accounting Research (IJEBAR)

Peer Reviewed - International Journal

Vol-5, Issue-1, 2021 (IJEBAR)

E-ISSN: 2614-1280 P-ISSN 2622-4771

https://jurnal.stie-aas.ac.id/index.php/IJEBAR

Uzliawati, L., \& Djati, K. (2015). Intellectual capital disclosure, corporate governance structure and firm value in Indonesian banking industry. International Journal of Monetary Economics and Finance, 8(2), 162-177. https://doi.org/10.1504/IJMEF.2015.070780 